\title{
REVIEW
}

\section{Phenylhydrazine haematotoxicity}

\section{Josef Berger}

Faculty of Health and Social Studies, University of South Bohemia, České Budějovice, Czech Republic

Received $16^{\text {th }}$ May 2007.

Revised $29^{\text {th }}$ June 2007.

Published online $6^{\text {th }}$ August 2007.

\begin{abstract}
Summary
Phenylhydrazine (PHZ) and its derivatives were first given a medical application at the end of the 19th century but with very little benefit. However, this compound seems to be very useful in models studying mechanisms of haemolytic anaemia. Phenylhydrazine induces a reactive oxygen species formation, peroxidation of lipids and oxidative degradation of spectrin in the membrane skeleton. PHZ-induced haemolytic injury seems to be derived from oxidative alternations to red blood cell proteins. This compound can modulate immune reactions.
\end{abstract}

Keywords: reactive oxygen species - membrane proteins - spectrin - haemolytic anaemia - mutagenity

\section{INTRODUCTION}

Phenylhydrazine (PHZ) was the first hydrazine derivative characterized by Hermann Emil Fischer in 1875. This compound is used worldwide mainly as a chemical intermediate in the pharmaceutical, agrochemical, and chemical industries. PHZ, C6H8N2 (see structural diagram below) has a molecular weight 108; it exists as yellow to pale brown crystals or as a yellowish oily liquid, with a freezing point of $19.6^{\circ} \mathrm{C}$ and a boiling point of $243.4^{\circ} \mathrm{C}$. PHZ metabolism seems to occur via ring hydroxylation and conjugation, excretion is

Josef Berger, Faculty of Health and Social Studies, University of South Bohemia, Emy Destinové, 37005 České Budějovice, Czech Republic

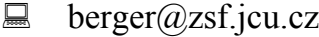

㙁+420389037401 primarily via the urine (McIsaac 1958, Cumming et al 1967).

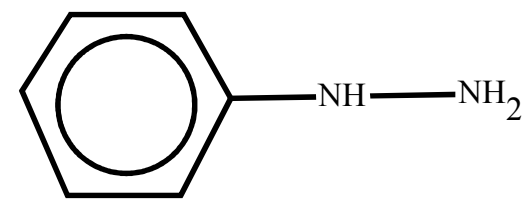

\section{PHENYLHYDRAZINE IN MEDICINE}

PHZ derivatives were used firstly as antipyretics but the toxic action on red blood cells made their use dangerous (Ranvers 1891). For many years phenylhydrazine was used for experimental induction of anaemia in animals until Morawitz and Pratt suggested it as a drug for polycythemia vera (Falconer 1933), a clonal disorder (Spivak 2002) which is known by a net increase in the total number of erythrocytes in the body.

Earlier in the last century, PHZ and phenylhydrazine hydrochloride were administered 
orally (usually around 100-200 mg/day) for the treatment of blood disorders (e.g., Giffin and Allen 1933). In some cases, treatment was effective; in others, however, the outcome was fatal (e.g., Giffin and Allen 1928, Giffin and Conner 1929).

PHZ decreases haemoglobin level, red blood cell concentration, and packed cell volume, and impairs erythrocyte deformability. It induces reticulocytosis, increased osmotic resistance, free plasma haemoglobin, mean corpuscular hemoglobin $(\mathrm{MCH})$, mean corpuscular hemoglobin concentration (MCHC), and erythropoietin levels, and extramedular haematopoiesis in the spleen and liver (cf, Hara and Ogawa 1975, Berger 1985a, Stern 1989). Although reticulosis is a typical reaction during erythropoietic stimulation induced by the decrease of erythrocyte concentration, the presence of elevated blood $\mathrm{O}_{2}$ tension may have suppressed erythropoiesis in goldfish (Houston and Murad 1995). During PHZ-induced acute anaemia, the numbers of erythrocyte-committed progenitors and colony-forming units increase (Terszowski et al. 2005).

This compound can induce vascular dysfunction and haemodynamic disturbance, and also, a decrease in mean arterial pressure and hindlimb vascular resistance (Luangaram et al. 2007). Uncompensated respiratory alkalosis, increased arterial $\mathrm{CO}_{2}$ tensions and acidosis were found following PHZ administration (Gilmour and Perry 1996, Pesquero et al. 2000).

PHZ-induced anaemia can be used as a model for the evaluation of its influence on therapeutic effectiveness, e.g., of antitumour therapy (Golab et al. 2002) or as a model of reticulocyte research (Xie et al. 2002) or erythrocyte senescence under abnormal physiological conditions (Xie et al. 2003). PHZ-induced anaemia is a model for the study of haematinic effects (Agbor et al. 2005, Biswas et al. 2005).

\section{TOXICITY AND MUTAGENICITY}

PHZ is toxic by single p.o. administration (LD50 $80-188 \mathrm{mg} / \mathrm{kg}$ body weight) and is expected to be toxic by the inhalation and dermal routes (Juany et al. 1996). This chemical has potential for skin and eye irritation in humans (cf. Rothe 1988).

Exposure to phenylhydrazine may cause damage to red blood cells, potentially resulting in anaemia and consequential secondary involvement of other tissues, such as the spleen and liver (cf, Stern 1989).

Phenylhydrazine can be mutagenic in vitro, and it may express genotoxic activity in vivo. It is carcinogenic in mice following oral dosing, inducing tumours of the vascular system. PHZ and phenylhydrazine hydrochloride have been investigated in a number of Ames tests (Shimizu et al. 1978, Tosk et al. 1979, De Flora 1981, Parodi et al. 1981, Levin et al. 1982, Malca-Mor and Stark 1982, Rogan et al. 1982, De Flora et al. 1984 a, b, Wilcox et al. 1990, Muller et al. 1993) and positive results have been obtained (Parodi et al. 1981, Malca-Mor and Stark 1982, De Flora et al. 1984 a, b, Rogan et al. 1982). PHZ was reported to be positive in a micronucleus assay in vitro (Suzuki 1985) while significant increase in the incidence of micronucleated polychromatic erythrocytes can be a consequence of induced haemolysis leading to more errors in nuclear expulsion without any indication of a direct genotoxic action.

DNA damage was assessed by measurement of the alkaline elution rate of single-strand DNA from mouse liver and lung tissue extracts after PHZ i.p. administration (Parodi et al. 1981).

\section{HAEMOLYTIC ANAEMIA}

The exposure to many chemicals including the administration of some drugs has been associated with red blood cell destruction (Beutler 2001, for review), and haemolytic anaemia is a part of the clinical syndrome associated with intoxication. Chemicals can cause haemolysis by interacting with sulfhydryl groups, the inhibition of various enzymes, immune mechanisms, and the fragmentation of erythrocytes as they pass through the platelet-fibrin mesh or by unknown or poorly defined mechanisms. In haemolytic anaemia, erythrocytes have a shortened life-span.

Heinz (1890) likewise found that mixing either nucleated (from cold blooded animals) or nonnucleated erythrocytes with $\mathrm{PHZ}$, turned them green-brown. He also discovered that inclusion bodies (now termed Heinz bodies) were formed in erythrocytes exposed to $\mathrm{PHZ}$ and that a number of compounds closely related to PHZ, e.g., Nacetylphenylhydrazine, could induce similar effects.

Yeshoda (1942) induced anaemia in rats following a single phenylhydrazine intraperioneal administration at a dose of $20 \mathrm{mg} / \mathrm{kg}$ b.w. (aqueous solution): erythrocyte concentration lowered to about $50 \%$ and haemoglobin level to about $60 \%$ of normal values in the course of 4 days.

Phenylhydrazine is used for the induction of haemolytic anaemia and the study of its mechanism in many species: rabbit (Hoppe-Seyler 1885, Brugnara and Defranceschi 1993, Nakanishi 2003, Xie 2003), rat (Yeshoda 1942, Berger 1985a), mouse (Golab et al. 2002, Paul et al. 1999), calf (Sharma et al. 1991), chicken (Datta et al. 1990), duck (Rigdon 1953), rainbow trout (Gilmour and Perry 1996, McClelland et al. 2005), Xenopus (Twersky et al. 1995), goldfish (Murad and Houston 1992), and in vitro also in both rat and 
human erythrocytes (Debray et al. 1967, McMillan et al. 1998, Pokhrel and Lau-Cam 2000, Claro 2006).

PHZ injected in a dose of $90 \mathrm{mg} / \mathrm{kg}$ b.w. to 8 wk old rats causes a decrease to $45 \%$ of normal erythrocyte concentration and packed cell volume to $53 \%$ on day 3 ; reticulosis to $475 \%$ on day 7 ; an increase in the mean cell volume to $170 \%$ and the highest increase from zero values in the count of erythrocytes with Howell-Jolly bodies on day 7, and both erythrocytes with Heinz bodies and normoblasts, as well as a $60 \%$ increase in mean cell haemoglobin on day 3 (Berger 1985a). The osmotic fragility increased over three days after anaemia induction (Berger 1985a, Redondo et al. 1995). This may be a consequence of reticulocytosis. The elevation of $\mathrm{MCH}$ referred to seems to be induced by a free plasma haemoglobin increase (Berger 1985a, Criswell et al. 2000). Reticulocyte counts are more sensitive than erythropoietin levels in predicting erythroid changes (Criswell et al. 2000).

Leucocytosis (Berger 1985a, Dornfest et al. 1992) with neutrophilia and lymphocytosis is at its maximum on day 3, hypersegmented neutrophils were observed rarely, phagocytosing blood lymphocytes are frequent on day 3 (Berger 1985a). Lymphocytes with butterfly-shaped nucleolus were also found (Berger 1985a).

PHZ treatment induces hypercellularity (Berger 1985a) with erythroid hyperplasia (Berger 1985a, Criswell et al. 2000).

Haemolytic anaemia induced by PHZ in rats may be detected based on hepatic changes in the expression of a subset of genes, Alas2, beta-glo, Eraf, Hmoxl, Lgals, and Rhced, that are mechanistically linked to haematotoxicity (Rokushima et al. 2007). This small gene subset was deregulated in all the severe haemolytic conditions, some of which were considered to be involved in hepatic events characteristic of haemolytic anaemia, such as haemoglobin synthesis, haememetabolism and phagocytosis elevation. As haemolytic anaemia can be induced also following phenacetin administration (Berger 1985b), identical genes are also expressed (Rokushima et al. 2007).

The availability of iron in a diet may modulate the regenerative response (Burkhard et al. 2001). Intensity of induced anaemia depends on age (Berger 1987, Naeshiro et al. 1998). The deepest anaemia was found in haemoglobin level, red blood cell counts and packed cell volume and reticulocytosis in old rats, while the highest increase in mean corpuscular volume (MCV) and MCV was found in young adult animals (Berger 1987). This could be due to the lower PHZresistance of mature red blood cells in elder animals.

\section{MECHANISM AT CELLULAR LEVEL}

PHZ increases reactive oxygen species (ROS) and lipid peroxidation, and decreases glutathione (GSH); these effects are reversed by $\mathrm{N}$-acetyl cysteine, a known ROS scavenger (Hill and Thornalley 1982, Clemens et al. 1984, Amer et al. 2004). Haemolytic anaemia has long been known to be caused by uptake of eryhthrocytes by macrophages in the spleen and translocation of phosphatidylserine from the inner to the outer of the plasma membrane has been identified as a signal for phagocytosis of cells under programmed death by macrophages. PHZ generates ROS within both human and rat erythrocytes; no evidence for lipid peroxidation or phosphatidyl serine externalisation was detected (deJong et al. 1997, McMillan et al. 2005).

ROS production was associated with extensive binding of oxidized and denatured haemoglobin to the membrane cytoskeleton. Thus, PHZ-induced haemolytic injury seems to be derived from oxidative alterations to red blood cell proteins rather than to membrane lipids (McMillan et al. 2005).

Vitamins $\mathrm{C}$ and $\mathrm{E}$ contribute to the decrease in oxidative stress caused by $\mathrm{PHZ}$ in vitro (Claro et al. 2006). They inhibited Heinz bodies and methemoglobin formation but they did not protect against GSH depletion by PHZ. Quercetin, an antioxidant bioflavanoid compound, also suppresses reactive oxygen and nitrogen species, and it partially protects reduced glutathione (GSH), malondialdehyde levels (Luangaram et al. 2007). Melatonin as a free radical scavenger protects against phenylhydrazine-induced oxidative damage to cellular membranes (Karbownik et al. 2000).

PHZ induces Heinz body formation and oxidative degradation of spectrin without any crosslinking of membrane proteins; both these findings impair erythrocyte deformability (Hasegawa et al. 1993). Formation of phenyl radicals and the replacement of haeme with phenyl-substituted protoporphyrins, causes the destabilisation of haemoglobins to induce Heinz bodies and haemolytic anaemia with PHZ (Nakanishi et al. 2003).

PHZ treatment increases the transport rates in $\mathrm{Na}-\mathrm{K}$ pump, Na-H exchange, Na-Li exchange, and $\mathrm{K}-\mathrm{Cl}$ cotransport in vivo, while a decrease in Na-K pump, Na-H exchange, Na-Li exchange and increase $\mathrm{K}-\mathrm{Cl}$ contransport were found in rabbit red cells (Brugnara and Defranceschi 1993).

PHZ modulate immune reactions.It was found to be mitogen and activator of lymphoid cells (Dornfest et al. 1990). 


\section{CONCLUSION}

Phenylhydrazine induces the destruction of red blood cells by oxidation stress and many joint changes at cellular levels resulting in haemolytic anaemia. PHZ-induced toxic anaemia offers a model for research into the pathogenesis of haemolytic anaemia and the influence of anaemia on other physiological processes or the course of associated diseases. PHZ-induced oxidative stress may serve as the model of the increased likelihood of cancer. Although changes in red blood cells after PHZ treatment are showed in many published papers, little seems to be known of PHZ effects on different types of cells.

\section{REFERENCES}

Agbor GA, Oben JE, Ngogang JY: Haematinic activity of Hibiscus cannabinus. Afr. J. Biotechnol. 4:833-837, 2005.

Amer J, Goldfarb A, Fibach E: Flow cytometric analysis of the oxidative status of normal and thalassemic red blood cells. Cytometry 60A: 73-80, 2004.

Beutler E: Hemolytic anemia due to chemical and physical agents. In Beutler E, Coller BS, Lichtman MA, Kipps TJ, Seligsohn U (eds): Williams Hematology, 6th edition, New York 2001, pp. 629-632.

Berger J: Screening of toxic-haemolytic anaemia in laboratory rats: a model of phenylhydrazineinduced haemolysis. Haematologia 18:193200, 1985a.

Berger J: Experimentally induced toxic-haemolytic anaemia in laboratory rats following phenaetin administraton. Folia Haematol. 112:571-579, $1985 b$.

Berger J: Age-related sensitivity of rats to induction of anaemia. Folia Haematol. 114:408-413, 1987.

Biswas S, Bhattacharyya J, Dutta AG: Oxidant induced injury of erythrocyte - role of green tea leaf and ascorbic acid. Mol. Cell. Biochem. 276:205-210, 2005.

Brugnara C, Defranceschi L: Effect of cell age and phenylhydrazine on the cation-transport properties of rabbit erythrocytes. J. Cell Physiol. 154:271-280, 1993.

Burkhard MJ, Brown DE, McGrath JP, Meador VP, Mayle DA, Keaton MJ, Hoffman WP, Zimmermann JL, Abbott DL, Sun SC: Evaluation of the eryhroid regenerative response in two different models of experimentally induced iron deficiency anemia. Vet. Clin. Pathol. 30:76-85, 2001.

Claro LM, Leobart MSS, Comar SR, do Nascimento AJ: Effect of vitamins C and E on oxidative processes in human erythrocytes. Cell Bioch. Funct. 24:531-535, 2006.

Clemens MR, Remmer H, Waller HD: Phenylhydrazine-induced lipid-peroxidation of red-blood-cells invitro and invivo monitoring by the production of volatile hydrocarbons. Biochem. Pharmacol. 33:17151718, 1984.

Criswell KA, Sulkanen AP, Hochbaum AF, Bleavins MR: Effects of phenylhydrazine or phlebotomy on peripheral blood, bone marrow and erythropoietin in Wistar rats. J. Appl. Toxicol. 20:25-34, 2000.

Datta K, Soni JL, Datta IC: An avian model for the study of acute hemolytic anemia in the domestic fowl (Gallus domesticus). Biomed. Biochim. Acta 49:607-611, 1990.

Debray C, Vaille C, Souchard M, Roze C: Action in vitro of phenylhydrazine and hydrogen peroxide on rat and human red cells. Pathol. Biol. 15:1167-1178, 1967.

deJong K, Geldwerth D, Kuypers FA: Oxidative damage does not alter membrane phospholipid asymmetry in human erythrocytes. Biochemistry 36:6768-6776, 1997.

Dornfest BS, Bush ME, Lapin DM, Adu S, Fulop A, Naughton BA: Phenylhydrazine is a mitogen and activator of lymphoid-cells. Ann. Clin. Lab. Sci. 20:353-370, 1990.

Dornfest BS, Lapin DM, Adu S, Naughton BA: Dexamethasone suppresses the generation of phenylhydrazine-induced anemia in the rat. Proc. Soc. Exp. Biol. Med. 199:491-500, 1992.

Falconer E: Treatment of polycythemia: the reticulocyte response to venesection, phenylhydrazin and radiation. Ann. Intern. Med. 7:172-189, 1933.

Fischer E: Über aromatische Hydrazinverbindungen. Ber. Dtsch. Chem. Ges. 8:589-594, 1875.

Giffin H, Allen E: Experiments with phenylhydrazine. I. Studies on the blood. Ann. Intern. Med. 1:655-676, 1928.

Giffin H, Allen E: The control and complete remission of polycythemia vera following the prolonged administration of phenylhydrazine hydrochloride. Am. J. Med. Sci. 185:1-13, 1933.

Giffin H, Conner H: The untoward effects of treatment by phenylhydrazine hydrochloride. J. Am. Med. Assoc. 92: 1505-1507, 1929.

Gilmour KM, Perry SF: The effects of experimental anaemia on $\mathrm{CO}_{2}$ excretion in vitro in rainbow trout, Oncorhynchus mykiss. Fish Physiol. Bioch. 15:83-94, 1996.

Golab J, Olszewska D, Mroz P, Kozar K, Kaminski R, Jalili A, Jakobisiak M: Erythropoietin restores the antitumor effectiveness of 
photodynamic therapy in mice with chemotherapy-induced anemia. Clin. Cancer Res. 8:1265-1270, 2002.

Hara H, Ogawa M: Erythropoietic precursors in mice with phenylhydrazine-induced anemia. Am. J. Hematol. 1:453-458, 1975.

Hasegawa S, Rodgers GP, Shio H, Schechter AN, Uyesaka N: Impaired deformability of Heinz body forming red cells. Bioreology 30:275286, 1993.

Heinz R: Morphologische Veranderung der rothen Blutkorperchen durch Gifte. Virchows Arch. Pathol. 122:112-116, 1890.

Hewitt R: The effect of phenylhydrazine hydrochloride on the peripheral blood picture in canares. J. Parasitol. 23:428-429, 1937.

Hill HAO and Thornalley PJ: Free radical production during phenylhydrazine-induced hemolysis. Can. J. Chem. 60:1528-1531, 1982.

Hoppe-Seyler G: Über die Wirkung des Phenylhydrazins auf den Organisms. Z. Physiol. Chem. 9:34-39, 1885.

Houston AH, Murad A: Erythrodynamics in fish recovery of the goldfish Carassius auratus from acute anemia. Can. J. Zool. 73:411-418, 1995.

Karbownik M, Reiter RJ, Garcia JJ, Tan DX: Melatonin reduces phenylhydrazine-induced oxidative damage to cellular membranes: evidence for the involvement of iron. Int. J. Biochem. Cell Biol. 32:1045-1054, 2000.

Long PH: Effect of phenylhydrazine derivatives in the treatment of polycythemia. J. Clin. Invest. 2:315-328, 1926a.

Long PH: Experimental anemia produced by phenyl-hydrazine derivatives. J. Clin. Invest. 2: 329-342, 1926 b.

Luangaram S, Kukongviriyapan U, Pakdeechote P, Kukongviriyapan V, Pannangpetch P: Protective effects of quercetin against phenylhydrazine-induced vascular dysfunction and oxidative stress in rats. Food Chem. Toxicol. 45:448-455, 2007.

McClelland GB, Dalziel AC, Fragoso NM, Moyes $\mathrm{CD}$ : Muscle remodelling in relation to blood supply: implications for seasonal changes in mitochondrial enzymes. J. Exp. Biol. 208: 515-522, 2005.

McMillan DC, Jensen CB, Jollow DJ: Role of lipid peroxidation in dapsone-induced haemolytic anemia. J. Pharmacol. Exp. Ther. 287: 868876, 1998.

McMillan DC, Powell CL, BowmanZS, Morrow JD, Jollow DJ: Lipids versus proteins as major targets of prooxidant, direct-acting hemolytic agents. Toxicol. Sci. 88:274-283, 2005.

Muller W, Englehart G, Herbold B, Jackh R, Jung $\mathrm{R}$ : Evaluation of mutagenicity testing with Salmonella typhimurium TA102 in three different laboratories. Environ. Health Perspect. 101:33-36, 1993.

Murad A, Houston AH: Maturation of the goldfish (Carrassius auratus) erythrocyte. Comp. Biochem. Physiol. A 102:107-110, 1992.

Naeshiro I, Yoshioka M, Chatani F, Sato S: Changes in the plasma erythropoietin level in rats following fasting, ageing, and anaemia. Comp. Haematol. Int. 8:87-93, 1998.

Nakanishi A, Kinuta K, Abe T, Araki K, Yoshda Y, Liang S, Li SA, Takei K, Kinuta M: Formation of meso, N-diphenylprotoporphyrin IX by an aerobic reaction of phenylhydrazine with oxyhemoglobins. Acta Med. Okayama 57: 249-256, 2003.

Parodi S, Taningher M, Russo P, Pala M, Tamaro M, Montibragadin C: DNA-damaging activity invivo and bacterial mutagenicity of 16 aromatic-amines and azo-derivatives, as related quantitatively to their carcinogenicity. Carcinogenesis 2: 1317-1326, 1981.

Paul A, Calleja L, Vilella E, Martinez R, Osada J, Joven J: Reduced progression of atherosclerosis in apolipoprotein E-deficient mice with phenylhydrazine-induced anaemia. Atherosclerosis 177:61-68, 1999.

Pesquero J, Alfaro V, Palacios L: Acid-base analysis during experimental anemia in rats. Can. J. Physiol. Pharmacol. 78:74-780, 2000.

Pokhrel PK, Lau-Cam CA: In vitro and in vivo effects of taurine and structurally related sulfur-containing compounds against phenylhydrazine-induced oxidative damage to erythrocytes. Taurine 4: Taurine and excitable tissues. Adv. Exp. Med. Biol. 483:503-522, 2000.

Ranvers : Über Pyrodin. Arb. A.d. erst. Med. Klin. Zu Berl. ii, 471, 1891.

Redondo PA, Alvarez AI, Diez C, Fernandezrojo F, Prieto JG: Physiological response to experimentally induced anemia in rats - a comparative study. Lab. Anim. Sci. 45:578583, 1995.

Rigdon RH: Acute anemia produced by phenylhydrazine hydrochloride in the duck observation on nucleated erythrocytes in vivo. Tex. Rep. Biol. Med. 11:110-121, 1953.

Rokushima M, Omi K, Araki A, Kyokawa Y, Furukawa N, Itoh F, Imura K, Takeuchi K, Okada M, Kato I, Ishizaki J: A toxicogenomic approach revealed hepatic gene expression changes mechanistically linked to drug-induced hemolytic anemia. Toxicol. Sci. 95:474-484, 2007.

Rothe A: Contact dermatitis from N-(alphachlorobenzylidene)phenylhydrazine. Contact Derm. 18:16-19, 1988.

Sharma ML, Soni JL, Atta K: Pathomorphological changes in calf erythrocytes during phenylhydrazine-induced acute hemolytic 
anemia. Arch. Exp. Veterinarmed. 5:45-78, 1991.

Shimizu H, Hayashi K, Takemura N: Relationships between the mutagenic and carcinogenic effects of hydrazine derivatives. Nippon Eiseigaku Zasshi. 33:474-485, 1978.

Spivak JL: Polycythemia vera: myths, mechanisms, and management. Blood 100:4272-4290.

Stealy CI, Sumerlin HS: Polycythemia vera: final report on a case under continual treatment with phenylhydrazine hydro-chloride for a years J. Am. Med. Assoc. 126:954, 1944.

Stern A: Drug-induced oxidative denaturation in red blood cells. Semin. Hematol. 26:301-306, 1989.

Suzuki Y: The development of a sensitive micronucleus test: an in vitro method using cultured bone marrow cells. Jikeikai Med. J. 100:709-719, 1985.

Terszowski G, Waskow C, Conradt P, Lenze D, Koenigsmann J, Carstanjen D, Horak I, Rodewald HR: Prospective isolation and global gene expression analysis of the erythrocyte colony-forming unit (CFU-E). Blood 105: 1937-1945, 2005.

Twersky LH, Bartley AD, Rayos N, Cohen WD: Immature erythroid-cells with novel morphology and cytoskeletal organizaton in adult Xenopus. Protoplasma 185:37-49, 1995.

Xie LD, Liu DH, Sun DG, Yao WJ, Gu L, Yan ZY, Wen ZY: Study on the membrane shear elastic modul and viscosity of reticulocytes. Progr. Biochem. Biophys. 29:776-780, 2002.

Xie LD, Gu L, Yan ZY, Yao WJ, Sun DG, Wen $\mathrm{ZY}$ : The microrheological changes in the course of erythrocyte senescence after phenylhydrazine injection. Clin. Hemorheol. Microcirc. 28:5-11, 2003.

Yeshoda KM: Phenylhyrazine anaemia in rats. Curr. Sci. 11:360-363, 1942. 